УДК 141.32(430)“19”М. Гайдегґер

DOI https://doi.org/10.32837/apfs.v0i28.942

І. П. Печеранський

ORCID ID: https://orcid.org/0000-0003-4722-2332

доктор філософських наук, доцент, професор кафедри філософії та педагогіки

Київського національного університету культури і мистеитв

\title{
КАНТІАНСЬКІ МЕДИТАЦІЇ МАРТІНА ГАЙДЕГГЕРА ПРО СУТНІСТЬ ЛЮДСЬКОЇ СВОБОДИ
}

Постановка проблеми. Вплив критичної філософії Імануеля Канта на творчу еволюцію Мартіна Гайдеггера (1889-1976) є вагомим і беззаперечним, а також постає цікавим предметом історико-філософського дослідження. У цьому ключі важливо прослідкувати перехід від праці «Буття і час» через суперечливий «поворот» у мисленні філософа, до творчості 1930-х рр., враховуючи роботу «Внесок у філософію» (Beiträge zur Philosophie), що охоплює проблеми істини i свободи. Важливо відзначити декілька моментів: по-перше, ранні роботи М. Гайдеґ'ера містили сильні, хоч і приховані ідеалістичні змісти та концепції, які згодом були артикульовані у працях 1930-х рр., по-друге, ці розробки головним чином базуються на діалозі мислителя з історією філософіï, i, по-трете, рання його творчість - кантівський проект, а пізня - опосередкований німецьким ідеалізмом розрив з більш ранньою кантівською позицією.

У рамках традиції німецького ідеалізму творчість пізнього М. Гайдег'ґера є розривом і водночас безперервним розвитком думки I. Канта. По суті, як і Фіхте, який вважав себе адептом кантівського проекту та водночас його критиком, М. Гайдегrер теж є критиком його ранніх творів і водночас тим продовжувачем роботи, що її розпочав кенігсберзький мислитель, реалізуючи найбільш базові онтологічні ідеї фундаментальної онтології всередині конститутивної буттєво-історичної структури, яка вже не є індивідуалістичною та аісторичною.

Однією 3 особливостей цього повороту до більш пізньої думки є новий акцент на практиці. М. Гайдегґер навіть заходить настільки далеко, що сприймає власні думки про практику як розвиток другої та третьої критик Канта, розвиток, який мав місце безпосередньо в розпал повороту, та привів вченого до творчості іншого відомого німецького ідеаліста Фрідріха Шеллінга, погляди якого багато в чому визначили період 1930-х рр.

Особливість так званого «повороту» у мисленні М. Гайдег'гера в основному зводиться до переоцінки практичної філософії І. Канта. На відміну від мислення через категорію «Я є», як це робив Кант у першій критиці, дослідник більше акцентує увагу на категорії «Я дію», що переважає у другій та третій кантівських критиках. Показовою роботою цього періоду є лекційний курс 1930 року «Сутність людської свободи", текст, на основі якого можна реконструювати розмисли М. Гайдеґгера про сутність засад і про сутність істини, які засвідчують сильний ідеалістичний ухил та, по суті, $€$ місцем зустрічі з практичною філософією I. Канта. Цей курс також містить найбільш виразні роздуми філософа про взаємозв'язок проблем істини, свободи та практики, які потребують ґрунтовного історико-філософського дослідження.

Аналіз останніх джерел і публікацій. Стосовно творчої та біографічної ліній М. Гайдеггера необхідно виділити дослідження В. Анца, Д. Барбаріча, В. Бімеля, П. Гайденко, Л. Гахмайстера, А. Денкера, М. Інвуда, Т. Кармана, Т. Кісєля, Д. Кьолера, А. Люкнера, Н. Мотрошилової, О. ПьоІгелєра, В. ван Реєна, Т. Ренча, Г. Феттера, Г. Фігаля, Г. Філліпсе, О. Ярауса та інших. Не можна обійти увагою праці, присвячені становленню гайдегґерового проєкту герменевтичної феноменології (Х. Адріан, Т. Вроблевскі, Кр. Деммерлінг, Є. Фальов, Г. Штенгер та ін.), а також специфіці «повороту» у його творчості (Д. Генріх, Ж. Гронден, I. Фегер). Що стосується української гайдеггеріани, то тут потрібно вказати на роботи таких авторів, як А. Баумейстер, А. Богачов, С. Возняк, А. Дахній, I. Держко, I. Карівець, В. Кебуладзе, Р. Кісь, Р. Кобець, М. Култаєва, М. Мінаков, Л. Сафонік, В. Суханцева, В. Терлецький та інші.

Мета статті - історико-філософський аналіз гайдеґгерівської інтерпретації кантового вчення про свободу у контексті взаємоінтеграції трансценденталізму й практичної філософії, переосмислення аристотелевих категорій «актуального» та «потенційного», проблеми каузальності, руху та кінечності.

Виклад основного матеріалу. Курс лекцій 1930 року засвідчує перехід мислення М. Гайдеґґера від трансцендентальної філософії до мислення практичної діяльності. Він передбачає спочатку обговорення проблеми істини в грецькій філософії, а потім - проблеми свободи в творчості I. Канта [7, p. 52, 93]. Він демонструє більш виразне мислення щодо кантівської концепції свободи, на відміну від інших рецепцій М. Гайдеґгера, особливо стосовно першої критики. Це 
пов'язано з тим, що вчений розглядає практичну філософію I. Канта більш інтегрованою в його трансценденталізм, і з цієї ж причини текст охоплює не лише фазу роботи, присвячену вивченню фундаментальної онтології, але й фазу буттєво-історичного мислення, нагадуючи, що цей поворот є більше зміщенням акценту, ніж відмовою від попередніх поглядів.

Частина тексту, що стосується проблеми істини, містить аналіз метафізики Аристотеля (Книга Тета, глава 10), який відіграє важливе підготовче значення для подальшої інтерпретації кантової концепції свободи [7, р. 57]. Аристотель розуміє буття як постійну присутність, що призводить до визначення істини як істини-буття та закладає підвалини для тривалого обговорення М. Гайдегґером категорій актуального та потенціального в Аристотеля як вирішення проблеми змін у структурі самого буття, яка є важливою проблемою, оскільки здатність матерії рухатися актуалізує проблему часу всередині буття. Це дослідження, яке М. Гайдеґгер згодом продовжив у лекційному курсі 1931 року, присвяченому аристотелевій метафізиці, є ще одним ключовим свідченням важливості понять актуальності та потенціальності для розгляду проблеми істини цього періоду. Ця дискусія виступає підгрунтям для розгляду М. Гайдеггером сутності людської свободи, оскільки актуальність у Аристотеля прямо пов'язана 3 пізнанням суті речі [5, p. 6-7]. Актуальність стосується того аспекту, який грецький мислитель пов'язує з істиною у формі буття. Теж саме стосується й розуміння сутності речі, що передбачає розкриття її істини в межах горизонту буття, адже йдеться про її константну присутність. Потенційність містить у собі міру перетворення на нову актуальність, розкриваючи проблему часу. Через те проблема актуальності та потенційності у Аристотеля є, по суті, проблемою істини, оскільки стосується як буття, так і часу. Проблема істини лежить в основі проблеми свободи, оскільки свобода - це частково здатність самості здійснювати спонтанний та автономний рух, висновок, який можна зробити, поєднавши кантівську дефініцію свободи та аристотелеві розмисли про актуальне та потенційне.

Рух є особливо важливою проблемою 3 огляду на підрив традиційного розмежування матерії та ідеї (наслідок розведення суб'єкта та об’єкта). Іншими словами, М. Гайдегґер поставив суб'єкта та об'єкт на один онтологічний рівень, внаслідок чого рух впливає на людину та на предмети у світі. Спроба Аристотеля відокремити рух, що виникає в душі під час мислення, від руху предметів, а форму від речовини, дала змогу розглянути рух виключно фізично, а революція М. Гайдеггера у переосмисленні себе і світу, означає, що Я рухаюсь на рівні своєї первісної конституції, рух само- cті, який вчений називає Bewegung, невіддільний від руху речей у світі. Крім того, можна інтерпретувати Аристотеля сучасними термінами у напряму уможливлення розуміння мислення на рівні фізичних рухів (приміром, функціоналістський та матеріалістичний погляд на душу). У будь-якому разі Аристотель наголошує, що «актуальність i потенційність не обмежуються просто сферою руху, а ширяться далі» [1, с. 1651]. Вони стосуються як розуму, так і душі. Т. Кісіель у роботі «Генеза буття та часу Гайдегґера» наголошує на тому, що німецький філософ ще у 1924 р. аристотелеве розуміння руху вважав важливим компонентом розмислів про істину як неприховане, пояснюючи, що вся практика і мислення - це сам рух, перехід від одного до іншого [8, p. 302]. Це розуміння допомогло М. Гайдегґеру розвинути уявлення про фактичність у Аристотеля та переосмислити свободу, що неминуче тягне за собою повернення до його розмислів про рух в рамках конституції Я. Тому Аристотель має важливе значення для розуміння вченим I. Канта. Ранній курс лекцій 1921-1922-го рр. «Феноменологічні інтерпретації Аристотеля» свідчить про це. М. Гайдеггер переосмислює рух природного світу як такий, що полягав у русі Я зі світом, оскільки світ сам конституюється зануренням Dasein у нього.

Цей ранній текст, який є інтерпретацією Аристотеля, згодом швидко перетворюється на дискусію про актуальність, під час якої грецький мислитель вже мало згадується. Це тому, що цей ранній приклад розмислів М. Гайдег'ера про актуальність знаходить своє відображення у переосмисленні аристотелевої категорії руху як категорії життя та самості, а не категорії фізичних змін. Дж. Протеві пояснює, що «життя - це Bewegung, pyх, що не $є$ локомоцією, Ortsbewegung, але метабола, наявність змін [Anwesendsein des Umschlagens]» $[11$, p. 155]. Вчений доходить висновку, що життя бере участь у постійному русі проти себе, перебуває у занепаді через те, що він спочатку назве розоренням, а згодом - падінням. Під час розорення Я завжди тягнеться до фактичності, а падіння настільки екстремальне, що тягне за собою не лише індивідуальний Dasein, але й світ та історію. Цей рух Я і матерії відбувається через те, що Я та світ не можна розділити. Переосмислення категорії руху в Аристотеля стосовно Я ні в якому разі не обмежує їх лише конституцією Dasein в цій ранній праці, швидше це призводить до розуміння спільного руху Я та світу. Це так, бо немає світу поза пережитим досвідом. М. Гайдеггер пояснює, що формально (і легко вводячи в оману) ми могли б сказати, що життя саме по собі пов'язане зі світом, що «життя» $\mathrm{i}$ «світ» не є двома окремими самодостатніми об'єктами, а також, що смисловий зв'язок, який поєднує їх, виражається у тому, що в характерних контекстах під час мовлення одне 
слово може заміняти інше [6, р. 65]. Звідси висновок, що занепад Dasein - це занепад світу, який відбудеться в історичному контексті, оскільки для М. Гайдеґґера темпоральність Dasein не існує окремо від прогресування речей у світі.

3 цієї позиції легше зрозуміти, наскільки актуальність і потенційність є важливими для більш пізнього М. Гайдегґера, який мислив дії Dasein в русі. Питання про актуальність та потенційність перетворюється на ще більш фундаментальніше у світлі того, що вчений ставить під сумнів сутність людської свободи. Вивчення сутності як актуальності передбачає виявлення сутності речі. Це питання стає ще більш точним, якщо врахувати, що сама свобода завжди включає здатність до змін. У кожному визначенні свободи, обговореному М. Гайдегґером, здатність Я до змін є проявом його свободи. Тоді питання про сутність людської свободи є питанням про актуальність людської потенційності: про спроможність Я до потенційних змін з огляду на природу свого існування як актуальності без нав' язаного та зовнішнього імпульсу.

Далі німецький філософ підходить до аналізу проблеми практики, оскільки вона прямо стосується людського існування та самого буття. Пізніше в лекції він зазначає, що для І. Канта практика має відношення не лише до етики, але й до фізичних змін. Через Аристотеля і Канта він демонструє необхідність вивчення практики для будь-якого дослідження буття, а дискусія навколо аристотелевої метафізики сама по собі є важливою частиною повороту М. Гайдегґера до ідеалізму. Як Нікомахова етика Аристотеля відіграла велику роль у кантівський період його творчості, так і метафізика відіграє важливу роль в ідеалістичній фазі його мислення. Ранні праці спираються головним чином на ідеї Аристотеля про людину, що має схильності та одержима фронезисом як практичною життєвою мудрістю. Хоча сучасна етика різко розділяє етику доброчесності та деонтологію, важливо усвідомити, що деонтологія майже повністю базується на другій кантовій критиці, ігноруючи інші способи побудови етики на основі вивчення розуму як трансцендентного, а не практичного агента. Одним із вагомих ранніх досягнень М. Гайдегера була інтеграція рис трансцендентальної філософії Канта 3 рисами практичної філософії Аристотеля, модифікуючи обидві позиції відповідно до фундаментальної онтології. Поняття трансцендентального Я, що має схильності, зовсім не суперечить трансцендентальній філософії.

Один із основних аргументів Аристотеля в Нікомаховій етиці полягав у тому, що Я є моральним агентом щодо оточення за допомогою предикатів в результаті зустрічей зі світом: досвід і дії визначають внутрішню конституцію принаймні до випадкових предикатів, які Аристотель називає чеснотами. Якщо прийняти більшість аргументів Аристотеля і відкинути його уявлення про себе як субстанцію, гайдегіерівська трансцендентальна філософія з їі практичним ухилом виявиться привабливою. Зрештою, трансцендентальне Я у вченого конституюється під час зустрічей зі світом, а також слугує передумовою для переживання світу, як і в Аристотеля, моральні зустрічі зі світом призводять до еволюції рис Я. Якщо взяти аристотелеву ідею «Я» і мислити її з точки зору предикатів, а не як суб’єкта, можна майже дійти до мислення Dasein.

Між іншим, одним із аспектів феноменологічної апропріації практичної філософії І. Канта є їі переупорядкування, щоб зумовити не лише моральні дії Я, але й долучити до своїх параметрів всі дії Dasein у світі, що спричиняють фізичні зміни цього світу та зміну в бутті Dasein. Оскільки Dasein і світ завжди в русі, істина частково зумовлена відновленням цього емпіричного зв'язку через саму свободу. Аргументи на користь цього стають очевиднішими, якщо подивитися на конституцію Я в «Бутті та часі», як на базову провину, закладену в самій його онтології. Ha Dasein лежить невідворотний рівень провини за всі випадки у світі, провини, яка виникає внаслідок ролі Dasein у формуванні самого світу, куди воно неминуче потрапляє. У цьому сенсі онтологія Dasein робить його моральним агентом на прикладі всіх дій у світі.

В ідеалістичний період відбувається переосмислення М. Гайдеггером свого раннього підходу до Аристотеля, а трансцендентальне переосмислюється на користь практичного або ж відбувається трансформація в трансцендентальну філософію ідеалістичного типу з акцентом на практичному. Замість того, щоб вивчати як Я обумовлює практичні зустрічі, мислитель зміщує фокус уваги на змогу історичної актуальності тримати та розкривати нові потенції в історії буття. Ця тема стає головною, оскільки дія, культурний розвиток та мислення формують світ через свободу Dasein. Тоді вивчення Аристотелем буття є набагато важливішим за вивчення Я на цьому етапі, адже Я та істоти, що рухаються навколо нього, є однаковими і всі фундаментально засновані на самій свободі. Це вимагає зустрічі з ідеалізмом, оскільки буття проявляється через історичне розгортання своєї потенційності завдяки Dasein. Caм Beitr ge далі показує, як актуальність і потенційність постають важливими аспектами привласнення ідеалізму М. Гайдегґером. Beitr ge бореться з тим, як подієвість може породити потенційно нове начало з горизонту актуальних історичних й культурних обставин. Актуальність та потенційність вивчаються в масштабі буттєво-історичного мислення та є темами, які резонують під час спроби розвинути гайдегґерівську політику з Beitr ge. 
У масштабі культури та історії актуальність та потенційність, мабуть, найважливіші поняття для формального вивчення політичної філософії загалом. Зрештою, політика - це сфера, яка вивчає соціальні відносини, як вони існують, а також як їх можна змінити, що підштовхує людину до питання про найкращій спосіб структурування соціуму, а також до питання, як насправді досягти цього покращеного стану.

Це також найважливіші теми пізнього I. Канта та ідеалістів. Я в дії - це Я, яке постійно бореться зі своїм власним потенціалом, оскільки воно існує в межах своєї дійсності. Відмовившись у своїй пізній роботі від причинно-наслідкового розуміння Я, І. Кант обгрунтовує розуміння себе як істоти, що має змогу діяти автономно. Вільне Я знаходиться поза каузальним ланцюгом природи, здатне задіяти нові потенції в умовах власної реальної свободи без примусу чи під впливом чуттєвої інтуїції. У другій частині лекції М. Гайдегґер намагається показати, як розмисли I. Канта про свободу, по суті, є дослідженням людського буття. Кантове дослідження свободи німецький дослідник поділяє на дві різні фази, які, зрештою, є двома сторонами однієї медалі. Насправді I. Кант подає два окремі визначення свободи та два засоби їі реалізації. Перший підхід розкриває трансцендентну свободу, а другий - практичну, але останній, до речі, паразитує відносно трансцендентального, будучи закладеним у самій критичній філософії. Тоді практичне й трансцендентальне стануть еквіпримордіальними, враховуючи, що гайдегґерівське мислення передбачає спільне функціонування передумов й дій світу в одному реляційному полі. Це чітко вказує на ідеалістичний синтез теорії та практики.

В заяві, яка відкриває лекцію 1930 р., Мартін Гайдеггер повертається до проблеми філософії як науки, стверджуючи, що вона цікавиться витоками та вивчає ціле. Особливо він порушує питання теорії та практики, узгодження яких є одним 3 головних проєктів ідеалізму, що, власне, він і намагається здійснити за допомогою двох підходів I. Канта до свободи. На прикладі вступу помічаємо, що вчений відмовляється прийняти злиття теорії і практики. Він хоче зрозуміти ці дві проблеми в рамках одного й того ж питання про засади, стверджуючи, що «філософія не є теоретичним знанням, як і практичним застосуванням, а також не $\epsilon$ теоретичним і практичним водночас. Вона первинніша за те і інше, адже обидва стосуються насамперед конкретних наук» [7, p. 14]. Можна вважати, що в лекції 1930 р. він ставить під сумнів нерозривність теорії та практики, які поєднуються в рамках його розмислу про істину. Саме тому цю лекцію можна розглядати як ідеалістичну за темою та натхненням, оскільки вона також вивчає свободу як основу істини, без якої не могла б існувати наука. У першій частині лекції йдеться про істину у світлі науково-теоретичного знання, а друга присвячена свободі в контексті етики та практики. Таким чином, ця лекція розкриває подвійне обгрунтування істини та практики в межах людської свободи, і вона досягає цього, використовуючи трансцендентальну та практичну свободу як підгрунтя для теорії та практики.

М. Гайдеггер експлікує трансцендентальну ідею Канта про свободу як абсолютну спонтанність Я в його каузальній здатності породжувати нові стани; відповідний практичний погляд на свободу, описаний у термінах автономії Я, ïï свободи від зовнішнього чуттєвого примусу. Останнє Iрунтується на першому, і тому він демонструє невіддільність практичної філософії від трансцендентальної - ідею, яка червоною ниткою пролягає від ранньої до пізньої його творчості. Трансцендентальна концепція свободи сама по собі $\mathrm{\epsilon}$ результатом розгляду М. Гайдегґером свободи в «Бутті та часі», адже Я здатне конструювати грані власної конституції та відповідності світу. Найважливішим та спільним для цих підходів до свободи питанням є питання про те, як Я проявляється у нових потенціях, які йому не нав'язані.

Питання про актуальність і потенційність лежить в основі, і одна із найгостріших суперечностей між цими концепціями свободи знаходиться у вченні І. Канта про причинність. Каузальність свободи спочатку, здається, відрізняється від каузальності природи, але виявляється, що різниця між ними полягає у виявленні каузальності свободи як певного виду причинності в рамках загальної структури причинності природи. Деривація практичної свободи від трансцендентальної свободи є одним із головних ключів до нової ідеалістичної ідеї свободи М. Гайдегґера. Цей висновок спирається на те, що трансцендентна свобода вже вимагає практичної свободи. Трансцендентальна свобода - це спонтанне породження нових станів самим Я, що перетворює іï на вроджено причинну. Практична свобода - це автономія Я. Ці два погляди на свободу від початку пов'язані актуальністю та потенційністю, оскільки було б неможливо спонтанно генерувати потенційні стани без фактичної автономії.

Висновок гайдеґгерової дискусії про Аристотеля та істину, в межах якої він переходить до обговорення I. Канта та проблематики свободи, $€$ одним із найбільш чітких прикладів того, як проблеми буття та істини стають проблемами свободи. М. Гайдег'ер вважає, що свобода є важливою, оскільки розкриває істину буття вільно і без примусу. Людина не є адміністратором чи арбітром свободи, натомість постає її співучасником. Дозволити бути стає важливим для свободи через іï онтологічну первинність, як тієї, що уможливлює Dasein. «Якщо свобода, - наголошує мислитель, - 
це основа можливості існування, корінь буття i часу, а отже, і основа можливості розуміння буття у всій його широті та повноті, тоді людина, грунтована у своєму існуванні на цій свободі, є місцем, де буття загалом розкривається, тобто вона є тим конкретним буттям, завдяки якому всі інші істоти як такі оголошують про себе» [7, р. 93-94]. Це твердження демонструє нове значення свободи у мисленні М. Гайдеггера, ще більш радикальний розрив з антропоморфною традицією та продовження його попереднього проєкту в рамках нової тематики свободи. Питання про конституцію Я i питання буття та часу все ще залишаються вирішальними, але тепер вони трактуються у світлі свободи, яка обгрунтовує буття та Dasein. Отже, головною вихідною характеристикою повороту $\epsilon$ не відкидання попередніх питань чи висновків німецького вченого, а новий спосіб мислення свободи на ідеалістичних засадах.

Більшість дискусій навколо кантової концепції свободи пов'язані з теорією каузальності. М. Гайдегґер ставить під сумнів те, що каузальний зв'язок лежить в основі зв'язку між свободою і підставою, що актуалізує питання руху. Далі ця частина лекції пронизана попередніми міркуваннями про актуальність та потенційність у тому сенсі, що гайдеггерове дослідження свободи у I. Канта здійснюється з урахуванням надзвичайно вагомого значення каузальності. Він зміцнює практичний розум, щоб продемонструвати його залежність від трансцендентного розуму, а також показує, що етика грунтується насамперед на свободі, яка своєю чергою базується на каузальності як результаті практичної свободи, що залежить від трансцендентальної свободи. Такий підхід сильно відрізняється від найпопулярніших версій кантової деонтології, які визнають раціональність складовою ознакою категоричного імперативу та розуміють, що він заснований на автономії Я. Логічні наслідки цього важко заперечити: категоричний імператив заснований на свободі, оскільки він базується на автономії, а ці розмисли про свободу грунтуються на першій критиці, бо саме в ній I. Кант вивчає саму раціональність як основу будь-якої етики.

Вивчати свободу крізь призму каузальності це вивчати її з позиції кінечності, оскільки будьякий каузальний зв'язок передбачає загибель. Далі М. Гайдеггер демонструє те, як пізні досліди I. Канта можна осмислити онтологічно з позиції каузальності. Кінечність Dasein перетворюється на кінечність знань у першій критиці та на кінечність свободи у другій. Тоді, як виявляється, проблема кінечності лежить в основі проблеми свободи, але замість того, щоб свобода грунтувалася на кінечності, остання базується на свободі. Людина смертна саме тому, що свобода вимагає кінечності існування. Свобода проявляє себе на рівні підста- ви, а сама причина є свого роду підставою, котра «виражає найглибшу сумнівність конституції живої та неживої природи» [7, р. 101].*

Час і каузальність кінечні за своєю природою і свобідна дія неможлива без обох цих компонентів, які створюють темпоральний контекст можливої дії, оскільки кантова концепція причинності передусім конституюється своїм відношенням до проблеми часу, тобто до спадкоємності у часі. М. Гайдег'ер виділяє у I. Канта два типи каузальності: причинність природи та причинність свободи. Причинність взагалі стосується природи, але існує особливий і більш вузький тип каузального зв'язку, який передбачає конкретно свободу і в той же час базується на більш загальних каузальних природних процесах. Це засвідчує роль, яку каузальний зв'язок відіграє під час визначення конституції людини та світу. Якщо свобода повинна передувати буттю та Dasein, тоді дуже важливо, щоб вона могла обгрунтувати їх конституцію.

Німецький мислитель переконаний, що для I. Канта саме причинність є проблемою, оскільки він намагається показати, що казуальні зв'язки в природі не створюють умов для Я, позбавляючи його свободи. Щоб кантове Я було вільним, воно повинно мати змогу з себе спонтанно розпочати новий причинно-наслідковий ряд. I це те, що намагається продемонструвати вчений, зазначаючи, що каузальний зв'язок сам по собі є трансцендентальною категорією розуміння, яка обов'язково включає в себе свободу як трансцендентальне поняття природи, щоб уможливити переживання останньої. Свобода не порушує причинність, а швидше зумовлює їі, адже лише на підставі вільної дії може початися ряд подій, утворюючи цілісність із серії явищ.

У той час як трансцендентальна свобода трактує можливу або потенційну свободу через каузальні зв'язки, практична свобода тлумачить фактичну свободу з позиції особистості, яка визначається як самовідповідальність, але для вченого насправді важливо те, що останній вид свободи полягає в тому, що практична актуальність $€$ результатом засадничої причинності. М. Гайдегґер переосмислює питання про причинність та свободу, щоб продемонструвати, що насправді саме свобода уможливлює каузальний зв' язок як тип темпорального буття.

Висновки. Отже, проведений аналіз кантіанських медитацій одного з найвідоміших філософів XX ст. Мартіна Гайдеґґера на тему повороту до техніки у його зв'язку з пізнанням сутності людської свободи дає підстави зробити наступні узагальнення.

У рамках традиції німецького ідеалізму, враховуючи вищезазначені проблеми, особливу увагу до себе привертає творчість пізнього М. Гай- 
деггера, що є розривом і водночас безперервним розвитком кантового проекту. Якщо говорити про так званий «поворот» у мисленні М. Гайдегґера, який в основному зводиться до переоцінки практичної філософії I. Канта, то важливим у цьому відношенні є його лекційний курс 1930 року «Сутність людської свободи», який містить роздуми філософа про взаємозв'язок проблем істини, свободи та практики.

Важливі пункти, які необхідно виділити в результаті гайдег'ерівської інтерпретації кантового проєкту:

- тісна взаємоінтеграція трансценденталізму та практичної філософії I. Канта;

- синтез кантової дефініції свободи та аристотелевих розмислів про актуальне та потенційне;

- революційний підхід М. Гайдег'ера у переосмисленні себе і світу полягав у тому, що Я рухається на рівні своєї базової конституції, рух Я, який вчений називає Bewegung, невіддільний від руху речей у світі;

- переосмислення динаміки природного світу як такої, що передбачає спільний рух Я зі світом, де останній конституюється зануренням Dasein у нього;

- аналіз категорії руху у Аристотеля, як такої, що застосовується до Я, не передбачає обмеження її лише конституцією Dasein в цій ранній праці, швидше це призводить до спільного руху Я та світу, адже останній не існує поза пережитим досвідом;

- занепад Dasein - це занепад світу, який відбудеться в історичному контексті, оскільки для M. Гайдеггера темпоральність Dasein не існує окремо від прогресування речей у світі;

- практичне й трансцендентальне є еквіпримордіальними, беручи до уваги те, що гайдеггерівське мислення передбачає спільне функціонування передумов й дій світу в одному реляційному полі, що чітко вказує на ідеалістичний синтез теорії та практики;

- висновок гайдеггерової дискусії про Аристотеля та істину, в межах якої він переходить до обговорення підходу I. Канта та проблеми свободи, є одним із найбільш чітких прикладів того, як проблеми буття та істини стають проблемами свободи;

- гайдеггерове дослідження свободи у I. Канта передбачає акцент на його залежності від трансцендентного розуму та від каузальності, а також показує, що етика грунтується насамперед на свободі, а та своєю чергою на каузальності як результаті практичної свободи, що залежить від свободи трансцендентальної;

- М. Гайдеггер переосмислює питання про каузальність та свободу, щоб продемонструвати, що насправді саме свобода уможливлює каузальний зв'язок як тип темпорального буття.

\section{Jimepamypa}

1. Aristotle. The Complete Works of Aristotle. Edited by Jonathan Barnes. Princeton: Princeton University Press, 1984. $1256 \mathrm{p}$.

2. Baiasu R., Vanzo A. (eds.). Kant and the Continental Tradition: Sensibility, Nature, and Religion. New York: Routledge, 2020. 255 p.

3. Engelland C. The Phenomenological Kant: Heidegger's Interest in Transcendental Philosophy. Journal of the British Society for Phenomenology, 2010, 41 (2), pp. 150-169.

4. Francois R., Pettigrew D., eds. Heidegger and Practical Philosophy. Albany: State University of New York Press, 2002. 390 p.

5. Heidegger M. Aristotle's Metaphysics Theta 1-3. Translated by Walter Brogan and Peter Warnek. Bloomington: Indiana University Press, 1995. 203 p.

6. Heidegger M. Phenomenological Interpretations of Aristotle. Translated by Richard Rojcewicz. Bloomington: Indiana University Press, 2001. xiv, 160 p.

7. Heidegger M. The Essence of Human Freedom: An Introduction to Philosophy. Translated by Ted Sadler. New York: Continuum, 2002. xiv, $216 \mathrm{p}$.

8. Kisiel T. The Genesis of Heidegger's Being and Time. Berkeley: University of California Press, 1993. $608 \mathrm{p}$.

9. Leśniewski N. Ontologization of Transcendentalism. Historical-Intentional Aspect of Heidegger's Interpretation of Kant's Critique of Pure Reason. Dialogue and Universalism, 2013, 23 (2), pp. 87-99.

10. Murai N. Heidegger's Transcendental Ontology and His Interpretation of Kant. In Shigeru Taguchi \& Nicolas de Warren (eds.), New Phenomenological Studies in Japan. Springer Verlag, 2019. pp. 121-138.

11. Protevi J. Political Physics: Deleuze, Derrida, and the Body Politic. London: The Athlone Press, 2001. 256 p.

\section{Анотація}

Печеранський І. П. Кантіанські медитації Мартіна Гайдеггера про сутність людської свободи. - Стаття.

У статті здійснюється історико-філософський аналіз гайдег'ґерівської інтерпретації кантового вчення про свободу у контексті взаємоінтеграції трансценденталізму й практичної філософії, переосмислення аристотелевих категорій «актуального» та «потенційного», проблеми каузальності, руху та кінечності.

У рамках традиції німецького ідеалізму, враховуючи вищезазначені проблеми, особливу увагу до себе привертає творчість пізнього М. Гайдеґґера, що є розривом і водночас безперервним розвитком кантового проєкту. Якщо говорити про так званий «поворот» у мисленні М. Гайдег'ера, який в основному зводиться до переоцінки практичної філософії І. Канта, то важливим у цьому відношенні є його лекційний курс 1930 року «Сутність людської свободи», який містить роздуми про взаємозв'язок проблем істини, свободи та практики.

У результаті аналізу кантіанських медитацій М. Гайдеґґера про сутність людської свободи, німецький вчений доходить тези про важливість тіснішої взаємоінтеграції трансценденталізму і практичної філософії; вдається до синтезу кантової дефініції свободи та 
аристотелевих розмислів про актуальне та потенційне; обґрунтовує думку, що Я рухається на рівні базової конституції, і цей рух Я, який він називає Bewegung, невіддільний від руху речей у світі; переосмислює динаміку фізичного світу, який не існує поза пережитим досвідом, що передбачає його коеволюцію та спільний рух з Я; відстоює тезу, що темпоральність Dasein не існує окремо від прогресування речей у світі; наголошує на ідеалістичному синтезі теорії та практики, а також обстоює думку, що проблеми буття та істини прямо пов'язані з проблемою свободи; дослідження свободи ставить у залежність від трансцендентного розуму та проблеми каузальності, показуючи, що етика грунтується насамперед на свободі, а та своєю чергою на каузальності як результаті практичної свободи, що залежить від свободи трансцендентальної; переосмислює питання про каузальність та свободу, щоб продемонструвати, що насправді саме свобода уможливлює каузальний зв'язок як тип темпорального буття.

Ключові слова: Мартін Гайдег'гер, Імануел Кант, кантіанські медитації, людська свобода, трансценденталізм, практична філософія, каузальність.

\section{Summary}

Pecheranskyi I. P. Kantian meditations of Martin Heidegger about human freedom essence. - Article.

In the article the historical-philosophical analysis of M. Heidegger interpretation of Kant studying about freedom is done in the context of mutual integration of transcendentalism and practical philosophy, rethinking of Aristotle's categories of "actual" and "potential", problems of causality, movement and finiteness.

In the boundaries of German idealism including above mentioned problems, special attention is drawn to the works of the late M. Heidegger which is a break up and simultaneously continuous development of Kant's project. If we are saying about so-called "turn" in M. Heidegger's thinking which is in main comes down to the revaluation of Kant practical philosophy, so the important in this situation are his lectures of 1930 "Human freedom essence" which contains thoughts about mutual integration of problem of truth, freedom and practice.

In the results of Kantian meditations' analysis by M. Heidegger about human freedom essence, the German scientist came to the thoughts about importance of closer mutual integration of transcendentalism and practical philosophy, dove in the synthesis of Kant definition of freedom and Aristotle's thoughts as for "actual" and "potential", substantiated the thought that I AM moves on the ground of based constitution and this movement I AM calls Bewegung; inseparable movement of things rethinking dynamics of physical world which does not exist out of overlived experience which implies its coevolution and joint movement with I AM, defended the thought that the temporality Dasein does not exist separately from progressive things in the world, emphasizes on idealistic synthesis of theory and practice and also defends the thought that the problem of essence and truth is directly connected with the problem of freedom; research of freedom makes us dependent on the transcendent mind and the problem of causality, showing the ethics is based first of all on the freedom and it, in its turn, on causality as a result of practical freedom which depends on transcendental freedom; rethinking the question of causality and freedom to demonstrate that it is in fact freedom that enables causal communication as a type of temporal being.

Key words: Martin Heidegger, Immanuel Kant, kantian meditations, human freedom, transcendentalism, practical philosophy, causality. 